This article was downloaded by: [ECU Libraries]

On: 24 April 2015, At: 11:59

Publisher: Taylor \& Francis

Informa Ltd Registered in England and Wales Registered Number: 1072954 Registered office: Mortimer House, 37-41 Mortimer Street, London W1T 3J H, UK

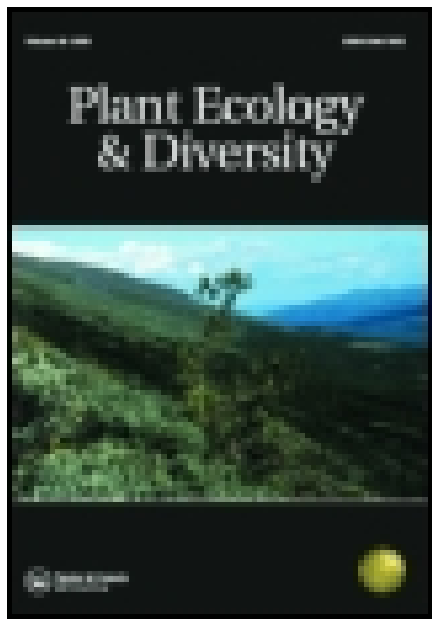

\title{
Transactions of the Botanical Society of Edinburgh
}

Publication details, including instructions for authors and subscription information: http:// www. tandfonline.com/loi/ tped18

I. Physical Features of the Central Part of British North America, with Special Reference to its Botanical Physiognomy

J ames Hector M. D. F.G.S. c.

Published online: 01 Dec 2010.

To cite this article: J ames Hector M.D. F.G.S. C. (1863) I. Physical Features of the Central Part of British North America, with Special Reference to its Botanical Physiognomy, Transactions of the Botanical Society of Edinburgh, 7:1-4, 167-196, DOI: $10.1080 / 03746606309467817$

To link to this article: http:// dx. doi. org/ 10.1080/03746606309467817

\section{PLEASE SCROLL DOWN FOR ARTICLE}

Taylor \& Francis makes every effort to ensure the accuracy of all the information (the "Content") contained in the publications on our platform. However, Taylor \& Francis, our agents, and our licensors make no representations or warranties whatsoever as to the accuracy, completeness, or suitability for any purpose of the Content. Any opinions and views expressed in this publication are the opinions and views of the authors, and are not the views of or endorsed by Taylor \& Francis. The accuracy of the Content should not be relied upon and should be independently verified with primary sources of information. Taylor and Francis shall not be liable for any losses, actions, claims, proceedings, demands, costs, expenses, damages, and other liabilities whatsoever 
or howsoever caused arising directly or indirectly in connection with, in relation to or arising out of the use of the Content.

This article may be used for research, teaching, and private study purposes. Any substantial or systematic reproduction, redistribution, reselling, loan, sub-licensing, systematic supply, or distribution in any form to anyone is expressly forbidden. Terms \& Conditions of access and use can be found at http://www.tandfonline.com/page/terms-andconditions 
may blow. . . . The island in the middle is constantly moist from the vapour of the Fall."

Mr Wm. Gorrie exhibited young trees of Pinus Laricio or Corsican Pine, and remarked that it was the best of all the European pines for deal timber, and the quickest in attaining a useful size. It has been used near Manchester for railway sleepers when only twenty years old.

E. B. Glass, Esq., Madras Civil Service, presented a packet of seeds of Argemone mexicana, the Jamaica prickly poppy, now naturalised in Hindostan.

Dr Alexander Dickson exhibited an abnormal peltate leaf, of a species of Gardenia.

$\mathrm{Mr} \mathrm{M} \times \mathrm{Nab}$ exhibited several growing ferns from Old Calabar, sent from time to time by the Rev. Mr Thomson.

13th June 1861.-Professor Balfour, V.P., in the Chair.

The following donations to the Society's Library were laid on the table:-

Observations de Tératologie Végétale, par M. Aug. le Jolis, Cherbourg.-From the Author.

Plantes Vasculaires des Environs de Cherbourg 1859, par Aug. le Jolis.-From the Author.

Lichens des Environs Cherbourg 1859, par Aug. le Jolis.From the Author.

Examen des espéces confondues sous le nom de Laminaria digitata 1855, par M. Aug. le Jolis.-From the Author.

Memoires de la Société Imperiale, des Sciences Naturelles de Cherbourg. TomeVII.-From Dr Jolis.

The following donations to the Museum of Economic Botany were announced:-

From Rev. Mr Thomson, Old Calabar-Stem, leaves, flower, and fruit of Physostigma venenosum (Balfour), Calabar ordeal bean; also, other fruits and seeds.

From Mr W. D. Paterson, Bridge of Allan-Stem of Plant from Cape of Good Hope. The wood is of exogenous structure, and exceedingly light.

Professor Balfour noticed the addition of Dr Greville's collection of Lichens to the University Herbarium. The collection consists of 64 genera and 498 named species, besides 86 sheets of unnamed specimens.

The following communications were read:- 
I. Physical Features of the Central Part of British North America, with Special Reference to its Botanical Physiognomy. By James Hector, M.D., F.G.S., \&c.

The following paper is intended as a sketch of the botanical results of a Government expedition which was sent out in the spring of 1857 to explore the British territories lying in the neighbourhood of the northern boundary line of the United States, and stretching westward from Lake Superior across the Rocky Mountains. The expedition was placed under the command of Captain Palliser, who had previously travelled among the Indians in the district of the Upper Missouri and Yellowstone Rivers. His party consisted of Lieutenant, now Captain Blackiston, R.A., who had charge of the magnetical observations; $\mathrm{Mr}$ Sullivan, as secretary and assistant-astronomer to Capt. Palliser; M. Bourgeau, a botanical collector whose name must be familiar to the members of this Society who have had occasion to consult the Herbarium; and the writer of this paper, who filled the post of surgeon and naturalist. The expedition was in the field for three years, and in that time examined and mapped a region embracing $33^{\circ}$ of longitude, and in some places $5^{\circ}$ of latitude.

Physical Characters of the Area explored.-Commencing at Lake Superior, the route of the expedition for the first 600 miles to Lake Winipeg, crossed over a spur which diverges to the south-west from an axis of crystalline rocks that runs from Canada to the Arctic Ocean in a north-west direction, and known as the "Intermediate Primitive Belt" of Richardson, or the "Laurentian Axis" of Logan. This belt of rocky country nowhere acquires a mountainous character, but is throughout extremely rugged and traversed by innumerable watercourses, and by long narrow lakes. The greatest altitude passed over in this portion of the journey was 1000 feet above Lake Superior, or 1600 feet above the sealevel. The inequalities of surface, and the diversity in the nature and amount of soil, has given a greater degree of complexity to the flora of this district than we might expect from its other physical conditions. The winter experienced in this 
region is severe, but steady. From the commencement of November till May the whole country is ice-bound, so that the vegetation is perfectly dormant. The spring is very lingering, owing to the great extent of surface occupied by water, and the neighbourhood of the large lakes on the one hand, and of Hudson Bay on the other, the slow melting of the ice which accumulates on these sheets of water keeping the temperature depressed till far on in the season. Thus, in crossing Lake Superior, on the 9th of June, the expedition encountered much cold weather, and got entangled in the ice floes that were, even so late in the season, drifting about the lake. The summer temperature is high, and for the same reason that renders the spring late, the autumn is prolonged beyond its normal extent, the influence of the large internal masses of water not having the effect of producing an equalised climate like that of a sea-coast, but merely prolonging the force exercised by the half-yearly extremes of heat and cold.

To the west of the Laurentian Axis commences the region of plains that extends to the eastern base of the Rocky Mountains, and north and south throughout the whole central district of the North American continent. In the neighbourhood of Lake Winipeg, the primitive rocks are overlaid by nearly horizontal strata of Silurian and Devonian age, consisting of limestones sometimes containing magnesia to such an extent that the soil derived from their decomposition must be of inferior quality. Excepting along the margins of the group of lakes that lie close to the axis, outcrops of these limestones are, however, rarely met with, the floor of the plateau being almost everywhere concealed by superficial deposits, consisting of sands, gravels, and marls, the bulk of which have been derived by denudation from the cretaceous strata that at one time must have overlaid the area now occupied by the chain of lakes that extends from Lake Winipeg to Great Bear Lake. A succession of steps, composed of these superficial deposits, and covered with a great profusion of erratic blocks, raises the level as we proceed westward, until, at an altitude of 1600 to 2000 feet, the finely assorted and wellmixed soils of the drift deposits cease, and the surface of the plain is occupied by strata of the age of the chalk, but 


\section{Dr James Hector on the Physical Features of the}

formed of plastic and sandy clays much impregnated with sulphates, and yielding little or no soil that can support vegetation. In some localities sandstones prevail, which disintegrate with facility, and give rise to immense wastes of blown sand, that are continually, though slowly, travelling before the prevailing winds.

The whole prairie-slope of the continent is divided into two regions by a low watershed, which traverses it from east to west, nearly following the political boundary, which is the 49th parallel of latitude, and throwing off the drainage, south to the Gulf of Mexico, and north to the Arctic Ocean and Hudson Bay. This watershed is very indistinctly marked, and has been formed entirely by denudation of the soft strata, being quite unconnected with any disturbance of the rocky framework of the basin. The prairies are traversed by several large rivers, but, excepting the sudden carrying off of the surface water when the snows melt in spring, these rivers can hardly be said to drain the country through which they flow, as their waters are derived throughout the greater part of the year from the Rocky Mountains; and the excess of evaporation over the rain-fall is shown by the drying up in summer of those streams that do not rise in the inountains or from the swampy region along their eastern base.

There is one physical feature, which has an important bearing on the question of botanical distribution, the effect of which will be alluded to in an after part of this paper. This is the manner in which the plains are traversed by deep and narrow valleys, with abrupt slopes, and cut into the otherwise level, or only slightly undulating surface of the country. Those troughlike valleys, by favouring variety in the exposure, soil, and drainage, have afforded continuous lines for the migration and diffusion of plants through tracts of country, where the prevailing conditions are quite unsuited for their support.

The plains rise gently as the Rocky Mountains are approached, and at their western limit have an altitude of 4000 feet above the sea level. With only a very narrow intervening belt of hilly country, the mountains rise almost abruptly from the plains, and present lofty precipices that frown like battlements over the level country to the eastward. 
When travelling in any of the transverse valleys, by which the chain is cut through almost to the prairie level, the mountains are seen to be composed of successive ranges formed by the escarpments of highly disturbed limestones and quartzites of palæozoic age.*

The average altitude of the highest part of the Rocky Mountains is 12,000 feet, but they never rise into marked peaks, and their cliff-like structure still further detracts from the grandeur of their appearance. The forest extends in altitude to 7000 feet; and as some of the passes are much under this elevation, the chain cannot be considered as a direct bar to the passage of the more striking kinds of vegetation.

Meteorological observations were obtained for the winter and spring seasons of both 1857-58 and 1858-59, at Fort Edmonton, which is situated in the plain country, and about 100 miles east of the Rocky Mountains, in Lat. $53^{\circ} 32^{\prime} \mathrm{N}$., Long. $113^{\circ} 20^{\prime} \mathrm{W}$., and at an altitude above the sea of 2000 feet.

In order to show more exactly the nature of the climate at these seasons of the year, the following abstract of the thermometric observations is given :-

I. From Daily Observations, excluding Maxima and Minima.

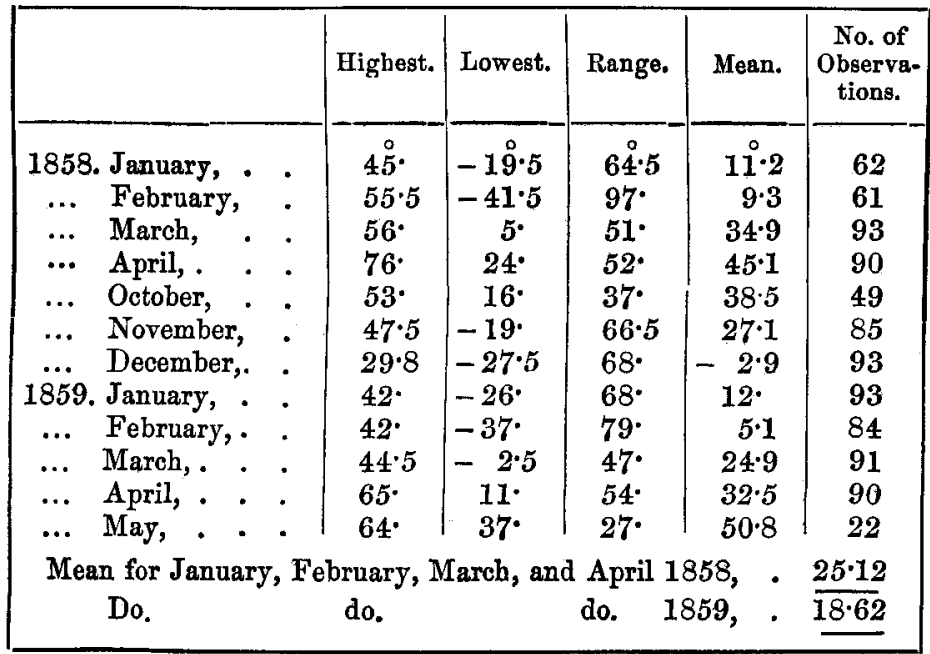

* A sketch of the geology of this country will be found in the "Geological Journal." November 1861. 
172 Dr James Hector on the Physical Features of the

II. From Daily Maxima and Minima Observations.

\begin{tabular}{|c|c|c|c|c|c|c|}
\hline & & \multicolumn{2}{|c|}{ Maxima. } & \multicolumn{2}{|c|}{ Minima. } & \multirow{2}{*}{$\begin{array}{l}\text { Mean } \\
\text { Tempera } \\
\text { ture. }\end{array}$} \\
\hline & & Highest. & Mean. & Lowest. & Mean. & \\
\hline 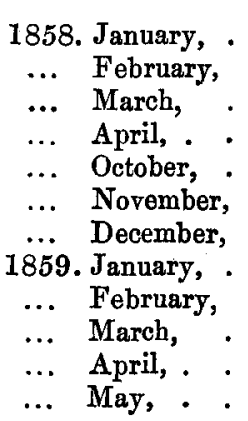 & - & $\begin{array}{l}\quad \circ \\
\ldots \\
\ldots \\
\ldots \\
\ldots \\
\ldots \\
52 \cdot \\
37 \cdot 5 \\
45 \cdot \\
43 \cdot 5 \\
44 \cdot 5 \\
67 \cdot \\
67 .\end{array}$ & $\begin{array}{c}o \\
\ldots \\
\ldots \\
\ldots \\
\ldots \\
\ldots \\
34 \cdot \\
6 \cdot 4 \\
20 \cdot 1 \\
13 \cdot 6 \\
34 \cdot 7 \\
41 \cdot 8 \\
58 \cdot 6\end{array}$ & $\begin{array}{c}-22 \cdot 5 \\
-41 \cdot \\
1 \cdot 5 \\
11 \cdot 5 \\
18 \cdot 5 \\
-2 \cdot \\
-25 \cdot \\
-35 \cdot 7 \\
-38 \cdot \\
-6 \cdot \\
0 \cdot 0 \\
31 \cdot\end{array}$ & $\begin{array}{c}-3 \cdot 3 \\
-3 \cdot 2 \\
22 \cdot \\
27 \cdot 9 \\
26 \cdot 2 \\
18 \cdot 9 \\
-14 \cdot \\
-1 \cdot \\
-11 \cdot 1 \\
11 \cdot 4 \\
20 \cdot 4 \\
37 \cdot 2\end{array}$ & $\begin{array}{c}\circ \\
\ldots \\
\ldots \\
\ldots \\
\ldots \\
\ldots \\
26 \cdot 45 \\
-7 \cdot 6 \\
9 \cdot 55 \\
1 \cdot 25 \\
23 \cdot 05 \\
31 \cdot 1 \\
47 \cdot 9\end{array}$ \\
\hline $\begin{array}{c}\text { Mean of Minima } \\
\text { Do. }\end{array}$ & & $\begin{array}{l}\text { a., Feb., } \\
\text { do. }\end{array}$ & March, & $\begin{array}{c}\text { nd April } \\
\text { do. }\end{array}$ & $\begin{array}{l}1858 \\
1859\end{array}$ & $\frac{21 \cdot{ }^{\circ} 7}{9 \cdot 8}$ \\
\hline
\end{tabular}

The climate of the prairies, and of the eastern slope of the Rocky Mountains, a district having a mean latitude of $53^{\circ} \mathrm{N}$., differs in many respects from that of the Eastern Lake District, the mean latitude of which is about $48^{\circ} \mathrm{N}$., although they possess nearly the same average temperature for the year. Thus, while the Canadian and Eastern climate is expressed by a low but steady winter curve of temperature, which is counteracted in its effect upon the vegetation by a correspondingly high summer curve, the manner in which the more northern and equally continental climate of the Western Saskatchewan acquires the same average, is by rapidly succeeding irregularities and variations of temperature, according to the direction of the dominant wind for the time. The influence exerted by those winds during the winter months was very clearly observed at Edmonton during the first part of the year 1858. They may be divided into three groups at this place:1. The clear winds, that in winter bring the intense extremes of cold, and which blow from the north-west. In summer, this direction is exactly reversed, when it becomes a clear, hot, and dry wind. This may be considered as the proper continental current, and is the wind of fine steady weather. It often only affects the lower stratum of the atmosphere, the 
clouds being seen to pass right across it in upper air. This wind must not be too rigidly defined by its mere direction, as it often blows from anomalous quarters, while its character remains the same, being quite subordinate in form to either of the next two groups, which are both stormy winds.

2. This group includes all the winds that generally blow from between north and east, and which in winter bring snow, and in summer cold fogs.

3. The south and south-west winds, that, blowing from the Pacific Ocean through and over the Rocky Mountains, always bring clouds, warmth, and sometimes even rain during the winter.

The struggle among these three climatic agencies gives rise to the following succession of phenomena. A few days of fine, steady, though perhaps intensely cold weather, with the wind from the north-west, is followed by a slight rise in the temperature, caused by the north-east wind having piled a canopy of cloud over the lower stratum, and so preventing radiation. This is effected gradually, every morning the sky being more and more overcast, and clearing later in each successive day, until at length it remains cloudy till evening, when a cutting north-east wind commences, that soon increases to a storm, followed by snow. This lasts for two or three days, till the snow begins to fall more gently, and with the temperature rising, at length the clouds break, when the upper stratum of air is seen moving rapidly from the south-west,carrying light fleecy clouds against a clear sky. Generally, in the course of the following night, the south-west wind affects the lowest stratum of air, and increases in violence, sometimes ranging rapidly through many points of the compass, showing that it takes the form of a cyclone, and at the same time bringing a high temperature and dense clouds discharging rain. One of these storms, for instance, passed over the Saskatchewan Plains on the $3 d$ of January 1858 ; and at Edmonton the minimum temperature for that day and night was $36^{\circ}$, while the maximum for the next twenty-four hours was only $10^{\circ}$. Again, on the 24th of the same month, at the close of another of these storms, the temperature fell from $37^{\circ}$ at 4 


\section{Dr James Hector on the Physical Features of the}

P.M., to $13^{\circ} .5$ before midnight, or a difference of $50^{\circ} .5$ in eight hours.

After the storm from the south-west has passed, the light north-wester generally sets in irregularly, and the temperature falls in the course of a few. days to an extreme, during which there is calm, followed by the haze and the overhanging cloud from the north-east as before.

Along the eastern base of the Rocky Mountains these changes are even more distinctly marked than in the longitude of Edmonton, and the effect they have in reducing the amount of snow is very remarkable, so that there is a narrow tract close to the mountains where there is never more than a few inches of snow on the ground, and the rivers, when rapid, remain open during the winter. In consequence of this, a few ducks are found to linger throughout the whole season in the mountains, while from the Plain country, in latitudes much further south, they are necessarily absent from October till May. Forty miles east of the mountains the snow-fall is much increased, but during the depth of winter rarely exceeds two feet in depth. From the prairies the snow evaporates rapidly, and excepting in hollows where it drifts, it never accumulates; but in the woods, where protected, it often reaches the depth of three to four feet towards spring.

During the steady cold of the winter the ground freezes to a considerable depth, especially in seasons when there is a small fall of snow. Thus at Edmonton the limit of the frozen soil was found on the 5th of March 1858 to be at the depth of nearly seven feet; and in the same spot in the year following, on the 16th of March, it was marked at six feet. Regular observations were taken during both winters, and also when travelling in the plains, for the purpose of ascertaining the temperature of the soil at the depth of two or three feet, according to the method suggested by $\mathrm{Dr}$ Hooker. The following table gives the means of these observations:- 
1857-8, Fort Carlton.

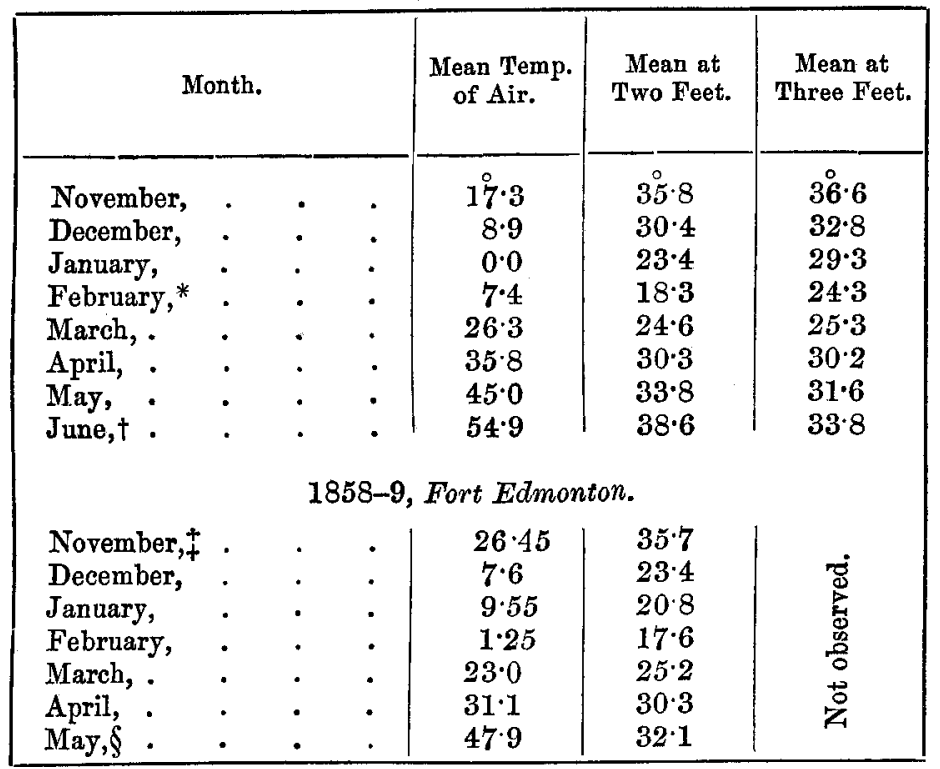

(The thermometers were sunk in brass tubes attached to a light wooden rod, and had the bulbs protected with flannel, to preserve them from the influence of the atmosphere while they were removed for examination.)

At Fort Carlton observations were also made by M. Bourgeau almost daily, in order to determine the temperature within the trunks of large trees. For this purpose thermometers were placed obliquely into the heart of a Populus balsamifera two feet in diameter, and of an Abies alba of the same size. These observations only served to show that, as might be expected, the temperature of the trees accords much more closely with the mean temperature of the atmosphere than does that of the soil, even at the depth of only two feet; and further, that there is no marked difference at very low temperatures between the resisting power of evergreen and deciduous trees. The means of these observations were as follows: $\|$ -

\footnotetext{
* First seventeen days only.

$\ddagger$ From 9 th to 30 th.

$\uparrow$ First eight days only.

\| Some of these observations have been printed in the Proceedings of the Linnean Society, 1859.
} 


\section{Dr James Hector on the Physical Features of the}

\begin{tabular}{|c|c|c|c|c|c|}
\hline \multicolumn{3}{|c|}{ Month. } & Air. & Poplar. & Spruce. \\
\hline $\begin{array}{c}1857 . \\
1858 . \\
\ldots \\
\ldots \\
\ldots\end{array}$ & $\begin{array}{l}\text { December, } \\
\text { January, } \\
\text { February, } \\
\text { March, . } \\
\text { April, . }\end{array}$ & $\begin{array}{l}\dot{.} \\
\dot{.} \\
\dot{.}\end{array}$ & $\begin{array}{r}8 \cdot 9 \\
0 \cdot 0 \\
7 \cdot 4 \\
26 \cdot 3 \\
\mathbf{3 5} \cdot 8\end{array}$ & $\begin{array}{c}9 \cdot 67 \\
0 \cdot \\
7 \cdot 11 \\
29 \cdot 27 \\
35 \cdot 54\end{array}$ & $\begin{array}{c}13.63 \\
0.8 \\
3.96 \\
20.93 \\
\ldots\end{array}$ \\
\hline
\end{tabular}

So long as the vegetation remains dormant during the winter season, the sudden changes which have been described, however great, can have little influence upon plant life; but when the mean temperature for the twenty-four hours rises above the freezing-point, and the powerful sun of each day, with the abundant moisture derived from the melting of the snows, stimulate the ascent of the sap and the germination of seeds, these sudden alternations must have a very baneful effect, and exclude from the flora of the country many plants that it would otherwise be quite fitted to sustain. From the middle of March until the third week of April is the usual duration of this critical period; but as late as the middle of May serious damage is frequently done to the vegetation by sudden variations of the temperature. This is without taking into consideration the night frosts, which are of common occurrence almost throughout the entire summer, and which, of course, must completely prevent the growth of many kinds of plants.

During the summer months, even in the true prairie country, rain, with cloudy weather, is much more frequent than might be expected from the position which the district occupies in the centre of a continent, and barred from the influence of the moist south-west winds by a continuous chain of mountains. On the prairies immediately to the west of the Red River settlement, as far as Turtle Mount, thunder-storms, with heavy rains, are of almost daily occurrence during the months of July and August. The temperature in that district was often very high, the thermometer several times reaching $95^{\circ}$ in the shade.

On the higher plains to the west, between Carlton and the Rocky Mountains, which range in altitude from 2000 to 
3000 feet, thunder storms are more rare, yet a good deal of rain falls. During the latter half of June 1858, there were nine days of rain and cloudy weather to six of fine clear sky. The mean temperature for the same period was $58^{\circ} \cdot 8$, from observations taken at sunrise, 2 P.M., and sunset, the highest recorded being $72^{\circ}$, and the lowest $46^{\circ}$. This excludes the minimum night temperature, however, which often fell within a few degrees of the freezing point. The mean degree of moisture in the atmosphere was 0.64 , saturation being 100 . During the month of July in the same year there were twelve days of cloudy sky and rain. The mean temperature was $59^{\circ} .5$, the extremes recorded being $70^{\circ}$ and $40^{\circ}$, with the degree of humidity 0.59 , or rather less than in June.

In August, in the district along the base of the mountains, having an altitude of nearly 4000 feet, the mean temperature was $54^{\circ}$, and the extremes recorded as occurring between sunrise and sunset were $79^{\circ}$ and $40^{\circ} \cdot 5$. Almost every night, however, we found that ice formed in the kettles, and that the ground was covered with hoar-frost.

The radiation, as might be expected, is very great during the summer nights in the northern prairies, so that when the sky is clear the quantity of dew that forms is great in proportion to the degree of moisture in the atmosphere. It is owing to this, combined with the sharp frosts in August and September, which arrest the sap before the grasses have fully flowered and faded, that the rich pasture along the North Saskatchewan plains is preserved green and juicy until the snow falls, after which the hard steady winter keeps. it fresh and nutritious as artificial hay until the return of spring. Along the South Saskatchewan the country is arid, and without such pasture; but in travelling in that region, no marked difference was observed in the frequency of rainclouds during the summer than when further to the north; and that a considerable amount of moisture passes over these plains is proved by the marked increase in the vigour of the vegetation on the high and isolated patches of table-land which are scattered over the arid country. It is probable that the prevalence of a hard clay soil, formed from the cretaceous strata, which bakes under the heat of the sun from 


\section{Dr James Hector on the Physical Features of the}

the want of moisture in early spring, is the immediate cause of this barrenness. The little snow which falls on the open plain is at once swept off by the wind and evaporated during the winter, so that in spring the clear powerful sun at once bakes the soil and prevents the germination of seeds.

The weather experienced in the Rocky Mountains was very irregular, with a great daily range of temperature. Thus, in the end of August the thermometer during the night was as low as $14^{\circ}$ at an altitude of 6000 feet, and almost every night it fell considerably below the freezing point, although during the day it often reached $70^{\circ}$ to $80^{\circ}$. In the valleys of the eastern slope the amount of rain-fall is very small compared to that on the first part of the descent to the west, when fine weather is the rare exception even in September. This only applies, however, to the mountains north of the fifty-first parallel of latitude, south of which, for some reason, the rainfall on the western slope in the valley of the Kootani River must be much less, judging both from the experience of two seasons and from the nature of the regetation, which is of the arid type.

On the eastern slope, throughout the entire summer, there are occasional falls of snow at altitudes above 5000 feet; but snow never lies deeply at any season. It is only on the various " heights of land" which have an altitude of from 6000 to 7000 feet, and for the first few miles of the western descent, that snow appears to accumulate in the valleys in large quantities-sometimes to the depth of 16 to 20 feet. The higher valleys of the central mass of the mountains are occupied by glaciers, some of which are of very considerable size, even when resting on the eastern slope. They are, however, fed principally by the snows that accumulate on the western slope, so that when ranges equally high are cut off from the influence of the western moisture, no glaciers have been formed. This exactly conforms to what has been observed by Dr Hooker and others regarding the diminished altitude of the snow-line as the nearest seaboard to a range of mountains is approached.

In the Latitude of $49^{\circ}$ the country to the west of the Rocky Mountains is very rugged and mountainous for the whole distance to the Pacific coast. South of that parallel, however, 
there are great expanses of desert plain, owing to the influence of the Cascade Range of mountains, which forms almost an unbroken wall 4000 feet in height, running parallel to the coast, and cutting off the moisture from the interior. In descending to the westward, therefore, from the Rocky Mountains, into the depression that intervenes between them and the Cascade Range, a belt of moist climate is met with where the winds that have passed over the coast-range first strike on the higher and interior range. Then follows a belt of dry climate, increasing in aridity as we proceed westward, and get more completely sheltered by the coast range, but on crossing which we at once get into the humid climate of the Pacific coast, with its wonderful development of forest growth.

Having thus briefly sketched the leading physical peculiarities which influence the character of the vegetation in the region treated of, I shall next give a short outline of the manner in which authors have divided British North America into botanical areas, and endeavour to show the position which the country explored by the Expedition occupies among them, as indicated by the collections of M. Bourgeau and by the physiognomy of its regetation.

The collections made by M. Bourgeau were forwarded to England from time to time, and were duly received by Sir William Hooker at the Royal Botanic Garden at Kew. They consisted-1st, Of plant specimens prepared for preservation in the herbarium; $2 d$, Seeds and roots of plants for culture, many of which have been successfully raised at $\mathrm{Kew}$; $3 d$, Specimens of the regetable products used in the country by the Indians, and which are preserved in the Kew Museum of Economic Botany. M. Bourgeau also made collections of insects and shelled mollusea, all of which were forwarded to the British Museum.

Of the dried plants, there were in general twelve specimens of each species sent home, and the duplicate sets have been distributed to the various public herbaria in Europe and America, including that of our own university, each specimen having been named before its issue from Kew by $\mathbf{M r}$ Black, curator of the Herbarium there, who prepared the list under the superintendence of Dr Hooker. 


\section{Dr James Hector on the Physical Features of the}

The collection of flowering plants and ferns consists of 819 species, belonging to 349 genera and 92 orders, which is more than two-fifths of the total flora of British North America. In the list, there are 62 species returned as undetermined, some of which will most likely prove to be new. In the relative order of their importance, from a number of species, the principal families stand thus:-

Compositæ form th of the whole.

$\begin{array}{llll}\text { Cyperaceæ } & \ldots & \frac{1}{12} \text { th } & \ldots \\ \text { Gramineæ } & \ldots & \frac{1}{18} \text { th } & \ldots \\ \text { Leguminosæ } & \ldots & \frac{3}{16} \text { th } & \ldots \\ \text { Rosaceæ } & \ldots & \frac{1}{16} \text { th } & \ldots \\ \text { Ranunculace } & \frac{1}{26} \text { th } & \ldots \\ \text { Cruciferæ } & \ldots & \frac{1}{28} \text { th } & \ldots \\ \text { Salicace } & \ldots & \frac{1}{28} \text { th } & \ldots \\ \text { Scrophulariace } & \frac{1}{28} \text { th } & \ldots\end{array}$

The following analysis of the collection will give a further idea of the general nature of the flora of the country from which it was made.

\begin{tabular}{|c|c|c|c|c|c|c|}
\hline \multirow{2}{*}{ Orders. } & & \multirow{2}{*}{$\begin{array}{l}\text { No. of } \\
\text { Genera. }\end{array}$} & \multirow{2}{*}{$\begin{array}{l}\text { No. of } \\
\text { Species. }\end{array}$} & \multirow{2}{*}{$\begin{array}{c}\text { Of which } \\
\text { andeter- } \\
\text { mined. }\end{array}$} & \multicolumn{2}{|c|}{$\begin{array}{c}\text { In British North } \\
\text { America. }\end{array}$} \\
\hline & & & & & Genera* & Species.* \\
\hline Ranunculaceæ, & . & 11 & 32 & $\ldots$ & 18 & 72 \\
\hline Menispermaceæ, & & 1 & 1 & $\cdots$ & 1 & 1 \\
\hline Berberideæ, & & 1 & 1 & $\ldots$ & 3 & 5 \\
\hline Sarraceniaceæ, & & 1 & 1 & $\ldots$ & 1 & 1 \\
\hline Nymphæaceæ, & & 1 & 1 & $\ldots$ & 3 & 4 \\
\hline Papaveraceæ, & & 1 & 1 & $\ldots$ & 3 & 3 \\
\hline Fumariaceæ, & & 1 & 2 & $\ldots$ & 4 & 9 \\
\hline Cruciferæ, . & & 14 & 31 & 7 & 25 & 104 \\
\hline Capparideæ, & & 2 & 2 & $\ldots$ & 2 & 2 \\
\hline Cistineæ, . & & 1 & 1 & $\ldots$ & 3 & 5 \\
\hline Violaceæ, . & & 1 & 8 & $\ldots$ & 1 & 18 \\
\hline Polygalaceæ, & . & 1 & 3 & $\ldots$ & 1 & 7 \\
\hline Droseraceæ, & & 1 & 1 & $\ldots$ & 2 & 9 \\
\hline Lineæ, . & & 1 & 2 & $\ldots$ & 1 & 3 \\
\hline Caryophyllex, & . & 6 & 17 & 3 & 12 & 66 \\
\hline Paronychiea, & & 1 & 1 & $\ldots$ & 2 & 2 \\
\hline
\end{tabular}

* These columns are given for comparison from Sir John Richardson's "Arctic Searching Expedition; 1851," vol. ii. p. 322. It is hardly necessary to remark that in this and the other works of this veteran explorer and philosopher, will be found generalizations respecting the climate and vegetation of British North America which the results of this expedition have only served to establish and apply for a very small area of the region which he treated of. 


\begin{tabular}{|c|c|c|c|c|c|c|}
\hline \multirow{2}{*}{\multicolumn{2}{|c|}{ Orders. }} & \multirow{2}{*}{$\begin{array}{l}\text { No. of } \\
\text { Genera. }\end{array}$} & \multirow{2}{*}{$\begin{array}{l}\text { No. of } \\
\text { Species. }\end{array}$} & \multirow{2}{*}{$\begin{array}{c}\text { Of which } \\
\text { undeter- } \\
\text { mined. }\end{array}$} & \multicolumn{2}{|c|}{$\begin{array}{c}\text { In British North } \\
\text { America. }\end{array}$} \\
\hline & & & & & Genera. & Species. \\
\hline Malvaceæ, & . & 1 & 1 & $\ldots$ & 3 & 5 \\
\hline Tiliaceæ, . & . & 1 & 1 & $\ldots$ & 2 & 2 \\
\hline Hypericinex, & . & 1 & 1 & $\ldots$ & 1 & 8 \\
\hline Acerineæ, & . & 2 & 3 & $\ldots$ & 2 & 8 \\
\hline Oxalidex, & . & 1 & 1 & $\ldots$ & 1 & 5 \\
\hline Geraniaceæ, & . & 1 & 4 & $\ldots$ & 2 & 6 \\
\hline Balsaminea, & . & 1 & 2 & $\ldots$ & 1 & 2 \\
\hline Rhamneæ, & . & 2 & 2 & $\begin{array}{l}\ldots \\
\ldots\end{array}$ & 2 & 6 \\
\hline Anacardiaceæ, & . & 1 & 2 & $\ldots$ & 1 & 6 \\
\hline Leguminosæ, & . & 13 & 50 & 7 & 26 & 98 \\
\hline Rosaceæ, & . & 16 & 48 & 7 & 24 & 124 \\
\hline Halorageæ, & . & 3 & 4 & & 4 & 10 \\
\hline Onagrariæ, & . & 3 & 13 & 2 & 6 & 28 \\
\hline Cucurbitaceæ, & . & 1 & 1 & 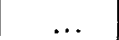 & 2 & 2 \\
\hline Cactaceæ,.. & & 1 & 4 & 4 & 1 & 2 \\
\hline Loasaceæ, & . & 1 & 1 & $\ldots$ & 1 & 3 \\
\hline Grossulariaceæ, & . & 1 & 7 & $\ldots$ & 1 & 16 \\
\hline Saxifragaceæ, & . & 4 & 15 & $\ldots$ & 8 & 56 \\
\hline Crassulaceæ, & . & 1 & 2 & $\ldots$ & 2 & 3 \\
\hline Umbelliferæ, & & 10 & 14 & 1 & 28 & 39 \\
\hline Araliaceæ, & & 1 & 3 & $\ldots$ & 3 & 7 \\
\hline Loranthaceæ, & & 1 & 1 & $\ldots$ & 1 & 1 \\
\hline Corneæ, & & 1 & 4 & $\ldots$ & 1 & 7 \\
\hline Caprifoliaceæ, & & 6 & 13 & $\ldots$ & 7 & 24 \\
\hline Rubiaceæ, & & 2 & 5 & $\ldots$ & 5 & 15 \\
\hline Compositæ, & & 40 & 112 & 8 & 70 & 321 \\
\hline Valerianaceæ, & & 1 & 1 & ... & 2 & 6 \\
\hline Campanulaceæ, & & 1 & 2 & $\ldots$ & 1 & 8 \\
\hline Lobeliaceæ, & & 1 & 1 & $\ldots$ & 1 & 6 \\
\hline Vaccineæ, . & & 2 & 5 & $\ldots$ & 1 & 16 \\
\hline Ericacex, . & & 7 & 9 & $\ldots$ & 10 & 40 \\
\hline Pyrolaceæ, & & 2 & 4 & $\ldots$ & 5 & 16 \\
\hline Primulaceæ, & & 7 & 10 & $\ldots$ & 8 & 23 \\
\hline Oleaceæ, & & 1 & 1 & $\ldots$ & 1 & 3 \\
\hline Gentianacex, & & 2 & 6 & $\ldots$ & 8 & 34 \\
\hline A pocynex, & & 1 & 2 & $\ldots$ & 1 & 4 \\
\hline Asclepiadere, & & 2 & 5 & $\ldots$ & 1 & 11 \\
\hline Polemoniacea, & & 3 & 5 & $\ldots$ & 3 & 13 \\
\hline Hydrophylleæ, & & 1 & 1 & ... & 2 & 5 \\
\hline Convolvulacex, & & 1 & 1 & $\ldots$ & $\mathbf{3}$ & 6 \\
\hline Solaner, . & & 2 & 5 & 2 & $\tilde{\mathbf{s}}$ & 8 \\
\hline Boraginaceæ, & & 8 & 17 & 2 & 5 & 27 \\
\hline Labiatæ, . & & 9 & 9 & .. & 24 & 40 \\
\hline Verbenaceæ, & & 1. & I & $\ldots$ & 2 & 7 \\
\hline Scrophularinex, & & 7 & 24 & 2 & 20 & 74 \\
\hline Lentibularieæ, & & 2 & 2 & ... & 2 & 8 \\
\hline
\end{tabular}


182 Dr James Hector on the Physical Features of the

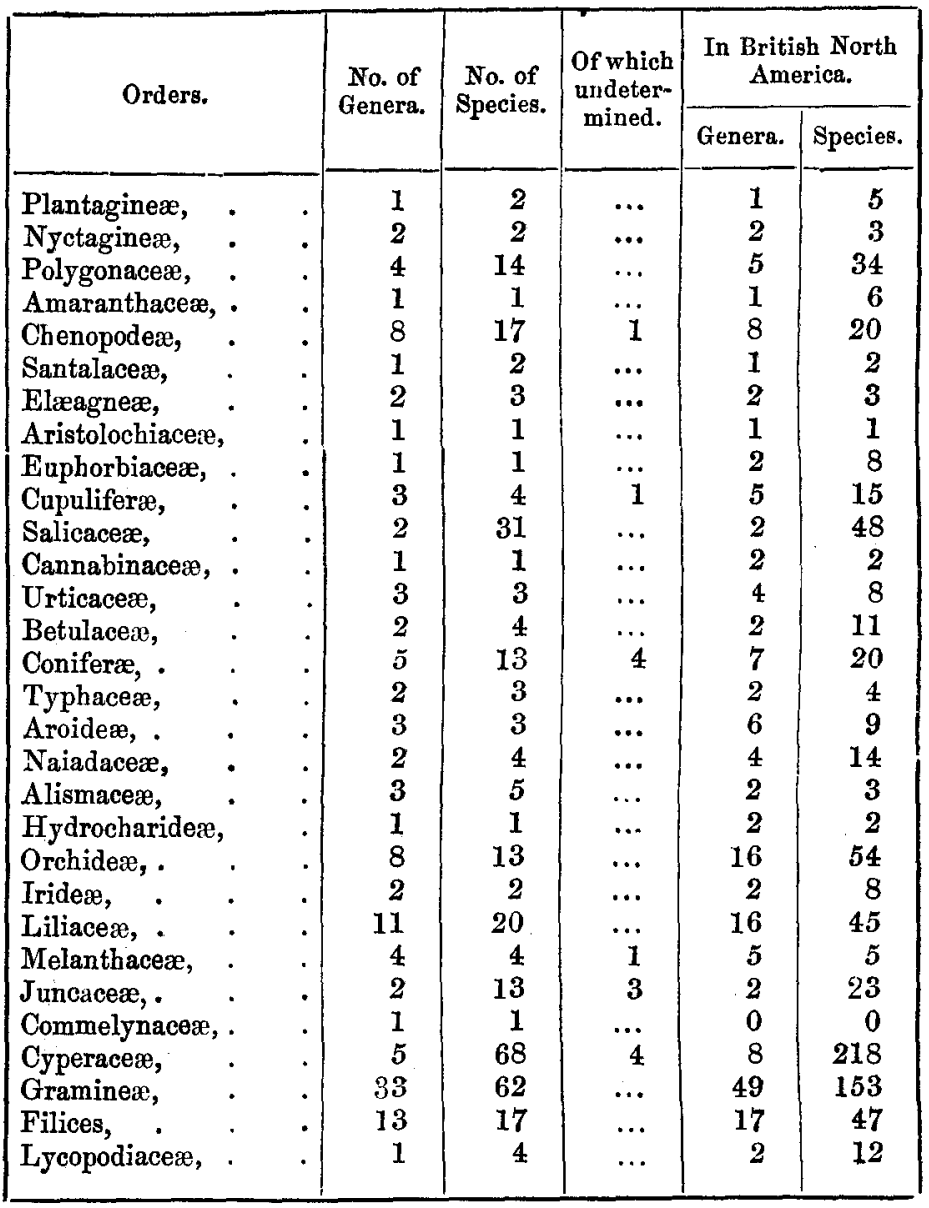

Summary of above.

1. In M. Bourgeau's collection,

$$
\begin{array}{r}
819 \text { species. } \\
349 \text { genera. } \\
92 \text { orders. }
\end{array}
$$

2. Of the same orders there have been enumerated by Richardson, as occurring in British and Russian North America-

471 genera;

2155 species-

the total flora which he enumerates; comprising

118 orders ;

509 genera;

2270 species;

viz., 1725 dicotyledons and 554 monocotyledons. 
In treating of the distribution of plants in British North America, Sir John Richardson* has divided the region into three zones, in the following manner:-

1. The Polar Zone, which embraces the land lying detached from the continent, and north of Lat. $73^{\circ}$. The flora of this zone consists of plants belonging to 21 natural orders, among which the Cruciferce, Graminea, and Saxifragacex, are the principal.

2. The Arctic Zone, which extends from the above-mentioned limit south to the Arctic Circle, excepting towards the eastern side of the continent, when, owing to the configuration of the land and the abnormal depression of the temperature, the characteristic Arctic flora passes for $10^{\circ}$ south of that limit. An outlier from this flora also passes the south along the ridge of the Rocky Mountains. The number of natural families is in the Arctic Zone increased to 67, and the most marked feature is the predominance of Cyperacece.

3. The Woodland Zone, which stretches across the continent obliquely, conforming to the divergence of the Arctic Zone from its proper latitudes, and thus lying between $45^{\circ}$ and $55^{\circ}$ of latitude on the Atlantic coast, but between $50^{\circ}$ and $60^{\circ}$ of latitude on the Pacific coast.

This zone he divides into three districts-

1. The Eastern Woodland district of Canadian Forest, which extends westward as far as Lake Winipeg.

2. The Western Woodland district, from the Pacific coast to the Rocky Mountains.

3. The Central or Plain district, lying east of the Rocky Mountains.

The number of natural orders represented in this zone is about 117 , being an increase of 50 over the number in the Arctic Zone.

As M. Bourgeau returned to England at the commencement of the third season's explorations without crossing the Rocky Mountains, his collection only consisted of the plants gathered from between Lake Superior and the eastern slope of that range. It thus represents a portion of Richardson's Eastern district, nearly the whole of the Prairie district that

* Arctic Searching Expedition 1851, vol. ii. App. No. 3. 


\section{Dr James Hector on the Physical Features of the}

lies within the British territory, and the alpine and subalpine district of the Rocky Mountains.

Until a thorough and critical analysis of the whole flora is accomplished, we cannot however expect much light to be thrown by the method of tabulation on the natural affinities which the floras of the different areas bear to one another; and till then it is therefore safer, in adapting provisional geographical groups, to rely more on the nature of the forest growth and such evident characters that catch the eye of the traveller. Such an analysis has however been recently effected for the flora of the northern part of the continent in a highly philosophical memoir by Dr Hooker " Outlines of the Distribution of Arctic Plants," read before the Lin. Soc. of London, June 21, 1861). His work has yielded most important results, modifying the generally received opinion of the uniformity of the Arctic flora throughout every longitude; and by tracing its distribution, he has found strong grounds for supporting the theory first promulgated by the late Edward Forbes, of a southern migration of northern types having taken place during the cold of the glacial epoch, and also of Darwin's view of the high antiquity of the Scandinavian Flora.

With regard to the northern flora of the American continent, Hooker has modified the areas described by Richardson, in so far as not distinguishing between an Arctic and a Polar flora, but merely dividing the whole region into an "Arctic West American Flora," which extends from Behring's Straits to $\mathbf{M}$ 'Kenzie's River, and an "Arctic East American Flora," which extends from that river to Baffin's Bay, but excludes Greenland, the flora of which he shows to belong to a European and not to an American type.*

Bearing in view the leading physical features of the country which have already been alluded to, and to the general botanical divisions that have been quoted, I shall now follow the course of the expedition, and briefly sketch the features of the vegetation observed along the route.

The canoe route from Lake Superior to Lake Winipeg, by which the spur of the eastern axis was crossed, passes

* I am indebted to the kindness of Dr Hooker in letting me have an opportunity of studying this valuable memoir while passing through the press. 
through a country that is on the whole heavily timbered, but the quality of the forest varies a good deal with the soil and elevation. Thus, round Thunder Bay, on Lake Superior, the ash, elm, maple, and cedar, with a rich undergrowth of rosaceous shrubs, are met with in addition to the white spruce, larch, pines of several species, birch and poplars ; but on the high lands round Dog Lake, elevated 1500 feet above the sea, the forest consists almost entirely of the latter trees. In descending to Rainy Lake, the more valuable timber reappears, wherever the soil is favourable to its growth, and such trees as Pinus resinosa, $P$. Strobus, and Cupressus thyoides, sometimes reach a large size. From Rainy Lake to the Red River Settlement, the forest becomes more varied and richer in its character, comprising elms, oaks, ash, basswood, (Tilia americana), beech, and iron wood (Ostrya virginica), but still with a large admixture of Coniferæ. In this district the undergrowth is very luxuriant, many of the shrubs of the Northern States occurring plentifully. On the borders of the lakes and rivers, the Indian rice (Zizania aquatica) is abundant, the grain of which, along with fish, forms the principal food of the Salteau Indians.

In proceeding due west from the Red River Settlement, the Prairie country is at once entered upon, being bounded to the north by the wooded country, the limit of which nearly follows the isothermal mean of $41^{\circ}$ in a northwest direction, until it reaches the 109 th meridian in Lat. $53^{\circ} \mathrm{N}$. , $^{*}$ when it sweeps again to the south-west to intersect the Rocky Mountain chain in Lat. $51^{\circ}$. The country to the north of the 49 th parallel, and up to the 55th, which was the region examined, is thus boldly marked into two districts by the presence or absence of timber. A third district must however be also considered, forming a belt dividing the forests from the true plains, and which at one time was itself forest-land, but having been cleared by the successive devastations of prairie fires, it now combines the advantages of both, having extensive ranges of open land like the prairies, which possess the rich vegetable mould, and

\footnotetext{
* It is probable that this isothermal, as generally represented, does not sweep enough to the south after crossing the Rocky Mountains from the west when passing through Long. $114^{\circ}$ to $96^{\circ}$.

TRANS. BOT. SOC., VOL. VII. 


\section{Dr James Hector on the Physical Features of the}

are covered with the nutritious grasses and leguminous plants of the forest country.

The woodland country which bounds the plains clearly possesses the physiognomy of the sub-arctic province. The most prevalent tree is the $A b i e s$ alba, which only reaches any great size in river valleys. On the dry rising grounds grows the Cyprés of the Canadian voyageurs; but under that name they include two different species of pines-P. Banksiana, and a pine allied to the $P$. inops of the United States, or to the $P$. contorta of the Pacific coast. A few of this latter species were seen near Fort Carlton, after which they were not again met with on a due west line until near the Rocky Mountains, south-west from Edmonton. The most important though not the most plentiful tree of the wooded country is the birch (Betula papyracea), as it is the only hard wood which the natives possess, and is used for making dog-sleighs, snow-shoes, and other necessary articles. These trees, with a few larches, balsam firs ( $A$. balsamea), red pines, poplars ( $P$. balsamifera, and $P$. tremuloides), comprise the bulk of the forest that covers the country to the north of the Saskatchewan; but by the sides of the rivers, which have generally deeply depressed valleys, there is of course a much greater variety in the vegetation, owing to the sheltered situation and the rich soil.

The belt of partially cleared country which lies to the south of the forest-land, and stretches continuously from the Red River Settlement to the Rocky Mountains, averages 80 to 100 miles in width, but it expands very much towards the west, owing to the bend which the southern border makes to the south-west. In this district the woods are very scanty, and consist almost exclusively of the aspen poplar, which forms small groves and artificial-looking clumps that dot rich pasture lands. Sometimes a small clump of spruce fir has been left by the fires, but this is only in a few rare localities, at least when at any distance from the limit of the true forest. Between Carlton and Edmonton, along the Hudson Bay Company's trail, for a distance of nearly 400 miles, there are not more than five or six spots where any of the Coniferæ have been left. The clearing of this country is due to a very simple cause. The prairie tribes of Indians, 15,000 to 16,000 in number, 
live wholly by the chase of the buffalo, and prefer, in consequence, to pitch their tents along the edge of the woods, for the sake of shelter, and at the same time to be near their game. Either by accident, or for the purpose of making signals, the prairies round their camps are generally burnt every few years, and, as a rule, where coniferous trees are destroyed, they are never replaced by the same stock; but the rich alkaline soil is at once seized upon by the wafted seeds of the aspen poplar, to the exclusion of other trees.

It is true that similar fires take place in the thick wood country and in the forests of the Rocky Mountains; but although they do much damage, the chance of their recurring on the same spot within a short enough time completely to remove the timber is small. Where the poplar seeds cannot reach such burnt spots, they are usually crowded with the gaudy plants of Epilobium angustifolium, among which the young pine seedlings can gain a footing, so that the forest often reverts in such a case to the coniferous type; but the thickets which spring up, strangely enough, very seldom contain plants of Abies alba, but almost invariably consist of the Pine which $I$ have alluded to as allied to $P$. inops.

The Saskatchewan and other rivers of the prairies flow through valleys rarely a mile in width, and excavated to the depth of 200 to 300 feet below the general level. The river winds from side to side of this valley, successively rounding rich alluvial flats, which sustain a rich and very different kind of regetation from that of the plains above. In such low situations, stragglers from the eastern flora are found to extend far beyond the western limit of where they continue to grow on the general surface of the country. Thus the false sugar maple (Negundo fraxinifolium) may be found as far west as Long. $108^{\circ}$ in the valley of the North Saskatchewan; and on an island in the same river, a short distance above Fort Carlton, the red eIm (Ulmus fulva) was observed. The oak follows up the valley of the Assineboine River as far west as Long. $100^{\circ}$. The true sugar-maple does not pass beyond the Red River, in which longitude is also found the western limit of the wild plum (Prunus americana), beech, ironwood, ash, cedar, arbor-vitæ, Weymouth pine, and other more 


\section{Dr James Hector on the Physical Features of the}

valuable trees of the eastern forest. Some of these were however seen by Richardson in the wooded country as far north as Lat. $54^{\circ}$. A few trees of Populus grandidentata were seen in the valley of the South Saskatchewan at its elbow, although that tree does not extend into the lower part of the valley of Red River from the Mississippi, where it grows in abundance.

Within the "fertile belt" of cleared land we have the vegetation on the alluvial flats of the river valleys, consisting of Populus balsamifera, which is the largest tree in that part of the country, sometimes reaching three feet in diameter, with a dense thicket of Salix longifolia, S. rostrata, Viburnum edule, Cratogus coccinea, Amelanchier canadensis, the wood of which is used for making bows, and the luscious fruit for mixing with pemican; Cornus stolonifera, or "red willow," the bark of which the Indians smoke along with tobacco. Shepherdia argentea sometimes forms the greater mass of the thicket, and its red juicy berries are the favourite food of grisly bears.

On the prairies of this district, besides the groves of the Populus tremuloides, or aspen, there are dense willow thickets surrounding the swampy ground. In such spots there is an immense variety of carices; and when, as is often the case, the water is saline, saliferous plants abound, and, as usual, generally of species having a wide range. On the sides of rising grounds the Eloeagnus argentea forms a low silvery copse, affording food to large coveys of prairie grouse. If the ground is high, or has a light sandy soil, it is then covered with a close matting of the Kin-i-kin-ic, or smoking weed, which is the Arctostaphylos Uva-ursi of the Scotch hills; or by the long flabelliform branches of Juniperus virginiana var. prostrata. Towards the mountains, large expanses of plain are covered with a low birch or alder (Betula glandulosa?), six to eight inches high, which in winter give the appearance of a heather-covered moorland to these prairies.

In June and July, in some localities, the prairies are covered with brightly-coloured flowers of the genera Astragalus, Hedysarum, Geranium, Lilium, and others, or are completely clothed with a dense low copse of rose bushes. As the country 
towards the south merges into open prairie, the clumps of copse and young poplars are found only nestling on northern exposures. The last outliers of the woods to the south form "islands," as they are called in the country, which make a great show from a distance, but when approached, are found by the disappointed traveller to consist merely of a small species of willow, that will yield neither firewood nor shelter.

The true arid district, which occupies most of the country along the South Saskatchewan, and reaches as far north as Lat. $52^{\circ}$, acquires even very early in the season a dry parched look. In the northern district, the accumulation of humus and the distribution of the pleistocene deposits have given rise to a great variety in the nature of the soil; but to the south, the cretaceous and tertiary strata almost everywhere form the surface, so that the stiff clay soil, which is often highly impregnated with sulphates of soda and lime, bakes under the heat of the sun into a hard and cracked surface. This must be the principal reason for the arid plains ranging to such a high latitude, as there is quite a sufficient quantity of moisture in the atmosphere during the summer months to support a more vigorous vegetation. This is seen to be the case even as far south as Lat. $49^{\circ} 30^{\prime} \mathrm{N}$., where, at the Cyprés Hills, and also on the south sides of the deep valleys and other exposures sheltered from the sun's rays in early spring, pines, sprucefirs, poplars, and many varieties of the northern type of vegetation, appear under congenial but strictly local conditions. In the arid country the characteristic plants are the prickly prairie apples (Opuntia), and the shrub-sage or absinthe (Artemisia); and in the trough-like valleys that lie east and west far out in the bare plains, these plants may sometimes be seen in full possession of the sunny slopes on the north side, while the opposite side of the valley is clothed with green and arborescent vegetation; while at the same time, showing that it is not local springs that cause the difference, the stream itself is often dried up into a chain of muddy pools. The arid district, although there are many fertile spots throughout its extent, can never be of much advantage to us 


\section{Dr James Hector on the Physical Features of the}

as a possession. Even in June and July, the Expedition experienced great inconvenience in traversing it, from the want of wood, water, and pasture.

Along the eastern base of the Rocky Mountains there is much fine land with very rich pasture; but the sharp night frosts which occur throughout the summer would render the raising of cereals very precarious. When close to the mountains, several trees appear which are found in greatest number on the west slope of the continent. Of these the principal is the "Prushe" of the voyageurs, which is so named by them from its general resemblance to the hemlock spruce (Abies canadensis). It is however a very distinct tree. Two pines were also observed that were not remarked further to the eastward, one of which is only slightly different from the Pinus monticola of Douglas. The collections obtained at the base of the mountains are not satisfactory, as, at the time of M. Bourgeau's visit, the season was too late for any plants but alpines.

The valleys of the Rocky Mountains are occupied by forests, excepting in a few localities, where there occur level gravelly plains clothed with tufts of "bunch grass" (Festuca). The forest consists principally of the Prushe, Douglas, white and black spruce. This mixed forest, with a very varied undergrowth, extends to 5000 feet in altitude, when it is succeeded by a forest of Abies balsamea. The tree that is found highest, however, is the Abies alba; and at an altitude of 7000 feet in exposed situations it is quite dwarfed in size, with recumbent branches that spread like thatch over the mountain sides. The altitude of the alpine region in the Rocky Mountains is very variable, and ranges from 7000 to 9000 feet. It is characterised by the occurrence of many plants of identical species with those found in similar situations in Europe.

The following is a list of some of the plants collected by the writer in the eastern part of the chain, in Lat. $52^{\circ}$ north, at an altitude of from 7000 to 9000 feet. They are all from one locality, near the height of land of a pass from the South to the North branches of the Saskatchewan River, and were gathered in the end of August 1859:- 
Silene acaulis, $L$.

Cerastium alpinum, $L$. arvense, $L$.

Stellaria longipes, Gold.

Fragaria virginiana, $E h r$.

Potentilla fruticosa, $L$. diversifolia, Lehm.

Epilobium alpinum, $L$.

Saxifraga bronchialis, $L$.

- controversa, Sternb.

- Dahurica, Pall.

Parnassia fimbriata, Hook.

Sedum stenopetalum, Pursh.

Youngia pygmæa, Ced.

Senecio triangularis, Hook.

Erigeron compositum, Pursh.

Valeriana capitata, (?) Willd.

Menziesia grandiflora, Hook.

Cassiope tetragona, G. Don.

Gentiana propinqua, Rich.
Castelleja minuta, Doug.

Polygonum viviparum, $L$.

Oxyria reniformis, Hook.

Salix reticulata, L. var. nana, Andr.

- arctica, $R$. Br.

Allium Schœnoprasum, $C$.

Ligadenus chloranthus, Rich.

Juncus ensifolius, $W i c k$.

- arcticus, Wick.

castaneus, $\mathbf{S} m$.

Luzula parviflora, Duv.

- spicata, $L$.

Poa alpina, $L$.

- pratensis, $L$.

Phleum pratense, $L$.

Bromus ciliatus, $L$.

Trisetum subspicatum, $P$. de $B$.

Festuca ovina, $L$.

Calamagrostis (Desyeuxia) coarctata, Torr.

On commencing the descent of the slope to the west, the change in the nature of the vegetation is very marked, showing a great increase in the amount of moisture which is deposited. Thus, high up on the sides of the valleys, there are dense thickets of Alnus viridis, which grows to the height of six and eight feet, with sturdy stems and branches. In the valleys, the forest is quite choked by an undergrowth of Thuja occidentalis, Mahonia Aquifolium, Panax horridum, Pyrus americana, Viburnum Opulus, along with species of Vaccinium, Ribes, Rubus, Symphoricarpos, and many other plants not observed on the eastern slope of the mountains. Wherever the valleys are rocky, the rocks are covered by a close growth of mosses and ferns, both of which groups are almost wholly wanting on the east side, excepting those mosses that grow in swamps. The forest is often impenetrable, from the interlocking of the trunks of fallen trees, many of which are three and four feet in diameter. When travelling with horses, it is difficult, where there is no trail, to get on faster than a mile or two a-day; and to make matters worse, amidst all this luxuriance of vegetation there is nothing that the poor animals can eat excepting a scanty growth of Equisetum, of which they are very fond, and which grows on the shingle flats of the 
mountain torrents along with a matting of Dryas and Epilobium, and other alpine plants, the seeds of which are washed down every spring.

On descending the mountains as far as the Kootani River, which flows south-east for eighty miles through a wide valley lying parallel with the direction of the chain, a marked change is again observed in the nature of the vegetation. The forest is free from undergrowth, and consists principally of the Pinus ponderosa, which in its habit much resembles the Scotch fir, and frequently reaches the size of four feet in diameter. Along with it is the Larix occidentalis, which is equal in girth, but exceeds the pine in height and symmetry. Amongst the noble forest which these trees form, a rider can gallop with ease in every direction, the only underbrush consisting of a few scattered bushes of the red root (Ceanothus) or of the Shepherdia argentea. On the alluvial flats by the river, the Juniperus virginiana was found as far north as $51^{\circ} 30^{\prime}$ to occur as a large tree 25 feet in height and 1 foot in diameter.

The surface of the ground, where dry and gravelly, is covered with wiry tufts of "bunch grass," and the slopes are clothed with a shrubbery of cherry and service-berry bushes (Amelanchier), the fruit of which is the principal food of the Kootani Indians. Westward from the Kootani River to Fort Colville, upon the Columbia, the country is very rugged, and when not confined in narrow valleys the forest generally forms open pine glades. By the sides of the streams and the low borders of lakes the yew and arbutus are found to occur, and in favourable spots the Thuja gigantea acquires an enormous size-often ten or twelve feet in diameter. Nevertheless, the prevailing physiognomy of the vegetation in this district is of the arid type; and further to the south, in the Columbian desert, this character is found to reach an extreme phase, there being a total absence of timber; and the country, even where the surface is irregular and rocky, supports nothing but a growth of dry tufty grass, or the worthless sage bush. (Artemisia tridentifolia). This sterility increases as we approach the Cascade Range; but on passing these mountains by the narrow chasm through which the Columbian River escapes to the Pacific, the change in the character of the vegetation 
is very abrupt. When sailing down that river from the Dalles to Fort Vancouver, in a distance of forty miles, the traveller passes from a desert flora to a country clothed by an evergreen forest of unrivalled variety and vigour. The scenery is magnificent, precipices of basaltic rocks rising from the water's edge tier above tier, to the height of several thousand feet, while in the distance occasional peeps are obtained of snow-capped peaks 10,000 to 12,000 feet above the sea-level.

On the western declivity of this mountain range, and on the narrow strip of country that lies between it and the coast, are found the beautiful and stately species of Abies, Picea, and $P$ inus, which have been introduced into this country from Oregon and $W$ ashington territories since the time of Douglas. The collections of that traveller, and those of Jeffrey, have made us familiar with the flora of the forest land along the Pacific coast; and our knowledge will be rendered still more complete by the ample collections of Dr Lyall, who is at present labouring in that country, attached to the N. W. Boundaryline Commission.

I am indebted to the kindness of Sir William Hooker for a memorandum which was left in his hands by M. Bourgeau, stating his opinion regarding the fitness of the Saskatchewan country for agricultural settlement, and a free translation of which I beg to append.

\section{Memorandum by M. Bourgeau.}

"I submit the following remarks on the advantages for agricultural settlement in Rupert's Land and the Sas. katchewan prairies of British North America, having been appointed by Sir William Hooker to accompany Captain Pal liser's Expedition as botanist.

"I had especially to collect the plants which grew naturally in the country traversed by the Expedition, and also their seeds. Besides my botanical collection, Dr Hooker advised me to make thermometrical observations at the various stations, and, above all things, to take the temperature of the earth at certain depths, as well as that of the interior of forest trees; also to notice the richness and poverty of the vegetation of the country, and the maladies to which plants are ex- 


\section{Dr James Hector on the Physical Features of the}

posed. In the second letter and notes addressed to Sir William Hooker, which have already been published,* I have treated these questions with all the care that was possible, by observations taken in the midst of the harrassment and fatigue of a long journey. It now remains for me to call attention to the advantage of establishing agricultural settlements in the vast plains of Rupert's Land, and particularly on the Saskatchewan in the neighbourhood of Fort Carlton. This district is much more adapted to the culture of staple crops of temperate climates-such as wheat, rye, barley, oats, \&c.- - than one would have been inclined to believe from its high latitude. The few attempts at the culture of cereals already made in the vicinity of the Hudson's Bay Company's trading ports, demonstrate by their success how easy it would be to obtain products sufficiently abundant to remunerate largely the efforts of agriculturists. There, in order to put the land under cultivation, it would be necessary only to till the better portions of the soil. 'The prairies offer natural pasturage as favourable for the maintenance of numerous herds as if they had been artificially formed. The construction of houses for habitations by the pioneers in the development of the country would be easy, because in many parts, independent of wood, one would find fitting stones for building purposes; and in others, more particularly near Battle River, it would be easy to find clay for brick. The other parts most favourable for culture are in the neighbourhood of Fort Edmonton, and also along the south side of the North Saskatchewan. In the latter district there are rich and vast prairies, interspersed with woods and forests, and numerous wood plants furnish excellent pasturage for domestic animals. The vetches found here, of which the principal belong to the genera Vicia, Hedysarum, Lathyrus, and Astragalus, are as fit for the nourishment of cattle as the clover of European pasturage. The abundance of buffalo, and the facility with which the herds of horses and oxen increase, demonstrate that it would be enough to shelter animals in winter, and to feed them in the shelters with hay collected in advance, in order to avoid the mortality that would result from cold and

* Proceedings of the Linnean Society. 1859. 
from the attacks of wild beasts, and further to permit the acclimatisation of other domestic farmyard animals, such as the sheep and pig. The harvest could in general be commenced by the end of August, or the first week in September, which is a season when the temperature continues sufficiently high and rain is rare. In the gardens of the Hudson's Bay Company's Posts, and still more in those of the different Missions, vegetables of the leguminous family, such as beans, peas, and French beans, have been successfully cultivated; also potatoes, cabbages, turnips, carrots, rhubarb, and currants. No fruit tree has as yet been introduced; but one might perhaps, under favourable circumstances, try nut-trees, also apple-trees belonging to varieties that ripen early. Different species of gooseberries, with edible fruits, grow wild here; also different kinds of Vacciniacece are equally indigenous, and have pleasant fruits that will serve for the preparation of preserves and confectionary. The Aronia ovalis (Amelanchier canadensis must be meant) is very common in this country; and its fruit, commonly known as the Poire, or service-berry, is dried and eaten by the Indians, who collect it with great care; and it also serves for the purpose of making excellent pudding, recalling the taste of dried currants. The only difficulty that would oppose agricuitural settlements, is the immense distance to traverse over countries devoid of roads, and almost uninhabited. The assistance of Government or of a well-organised company, would be indispensable to the colonization of this country. It would be important that settlements should be established in groups of at least fifty householders, for protection against the incursions of the Indians, who are, however, far from being hostile to Europeans. It stands to reason, that the colonists ought to be taken from the north of Europe or from mountain districts, being those accustomed to the climatological conditions and culture of the soil most resembling this interesting country, to the resources of which $I$ call attention. The produce of agricultural settlements thus established would yield subsistence to the Indians, whose resources for food, supplied only by hunting, tend to diminish every day. The presence of European settlers would form a useful model for this primitive 
196 Biograplical Sketch of the late Professor Henslow.

people, who, notwithstanding their native apathy, still appreciate the benefits of civilization."

(Signed)

"E. Bourgeau."

I may state, in conclusion, that the views here expressed by M. Bourgeau accord on the whole with the opinion I myself have formed of the fertile portion of the Saskatchewan country, and which $I$ believe is also that of the other members of the Expedition.

\section{Biographical Sketch of the late Professor Henslow. By Professor Balfour.}

I have this evening to record the death of one of the early Fellows of the Botanical Society, who was enrolled on the 12th of January 1837. The Rev. John Stevens Henslow, Professor of Botany in the University of Cambridge, was born at Rochester on the 6th of February 1796, where his father was a solicitor. He was the eldest of eleven children, of whom four sisters only survive him. His grandfather was Sir John Henslow, surveyor of the navy. He was educated first at the Free Commercial School at Rochester, and afterwards at Camberwell, in Surrey, under the late Rev. W. Jephson, D.D. At the latter institution he acquired a taste for collecting, arranging, and illustrating objects of natural history. This became a ruling passion through life, and placed him in a high position as a benefactor of mankind. He entered St Jolın's College, Cambridge, in October 1814. He graduated B.A. (16th Wrangler) in 1818 , and in the same year he was elected a Fellow of the Linnean Society. During his college career he devoted himself assiduously to science, which in those days did not occupy a prominent position in the University of Cambridge. He studied chemistry under Professor Cumming, and mineralogy under Dr Clarke. He also prosecuted geology with vigour, and in 1819 became a Fellow of the Geological Society. In 1821 he passed on to M.A., and during that year he communicated to the Geological Society "Observations on Dr Roger's account of the Isle of Man," and to the Cambridge Philosophical Transactions an account of the Geology of the Isle of Anglesea. In 1822 he was elected 